\title{
Effects of Static Magnetic Field Exposure on Hematological and Biochemical Parameters in Rats
}

\author{
Salem Amara ${ }^{*}$, Hafedh Abdelmelek ${ }^{1}$, Mohamed Ben Salem ${ }^{2}$, Rached Abidi ${ }^{3}$ and Mohsen \\ Sakly ${ }^{1}$ \\ ${ }^{1}$ Laboratoire de Physiologie Animale; ${ }^{2}$ Laboratoire de Physique des Matériaux, Faculté des Sciences de Bizerte; \\ Jarzouna 7021; Tunisie. ${ }^{3}$ Laboratoire d'Hématologie, Hôpital Régional de Bizerte, Tunisie
}

\begin{abstract}
The present work was undertaken in order to investigate the effects of static magnetic field (SMF) on growth rates, hematopoiesis, plasmatic proteins levels, glucose concentration, lactate dehydrogenase (LDH) and transaminases activities in male rats. Sub-acute exposure of rats during 5 consecutive days to SMF (1h/day at 128mT) induced an increase of plasma LDH activity (+38\%, $p<0.05)$, and glucose concentration (+31\%, p<0.05), whereas haematological parameters, protein levels, alanine aminotransferase (ALT) and aspartate aminotransferase (AST) activities remained unchanged. SMF exposure of rats during 30 consecutive days (1hour/day at $128 m T$ ) decreased significantly growth rates by the second week and increased significantly the plasmatic total protein levels $(+62 \%$, $p<0.05)$, hemoglobin $(+10 \%$, $p<0.05)$, red blood cells $(+7 \%, p<0.05)$, white blood cells $(+17 \%, p<0.05)$, and platelet number $(+10 \%$, $p<0.05)$. Sub-chronic exposure to SMF increased also LDH $(+43 \%, p<0.05)$, AST $(+41 \%$, $p<0.05)$ and ALT activities ( $+95 \%, p<0.05)$. In contrast, the glucose concentration was unaffected. These changes suggested that exposure to SMF had a possible effect on the proliferation of blood cells and enzymes release within blood indicating tissue alterations.
\end{abstract}

Key words: Static Magnetic Field, Transaminases, Haematopoiesis, Glucose, Rat

\section{INTRODUCTION}

In recent years, several studies have suggested possible bio-effects of magnetic fields on human health (Jolanta et al., 2001). Epidemiological studies have failed to find a correlation in live subjects between the continuous presence of magnetic field at different intensities and the appearance of any particular pathology (Reipert et al., 1997; Hatch et al., 1998; Lacy-Hulbert et al., 1998; Day, 1999). In contrast, several investigations have demonstrated an increase in childhood leukemia and other related diseases in children from populations exposed to electro- magnetic fields (Thomson et al., 1988). Moreover, an increasing number of reports indicate that magnetic field is involved in cancer induction as co-carcinogenic factors able to enhance the effects of other mutagenic substances (Baum et al., 1995; Mevissen et al., 1995). Biochemical studies have been carried out to evaluate the effects of magnetic field on the metabolism of cell cultures, animals and humans (Kula et al., 1991). Previous reports showed significant disruption in the carbohydrate, lipid and protein metabolism reflected by altered blood glucose levels and accelerated glycolysis and glycogenolysis (Boguslaw et al., 1999) Magnetic field is known

${ }^{*}$ Author for correspondence 
to be strongly lipolytic and glycogenolytic in rats (Chemysheva, 1990; Gorczynska et al., 1991), inducing a prominent increase in blood glucagon, cortisol and thyroxin levels. More invasive studies have been performed in animals. High et al (2000) found that exposure of rats to SMF had no significant effects on spatial memory, incidence of death, changes in heart rate, body weight, food and water consumption. Exposure of mice to static magnetic field suppressed the eating and drinking behaviour and increased the blood urea nitrogen, glucose and creatinine concentrations (Kula et al., 1991). The magnetic field exerted a preponderate controlling influence on the thermoregulation, metabolism and haematology in rats (Marino et al., 1995; Bonhomme et al., 1998; Abdelmelek et al., 2000; Nagashima et al., 2000; Abdelmelek et al., 2001). Considering the lack of consensus on the biologic effects of static magnetic fields, this work aimed to investigate the effects of SMF exposure on blood cells count and plasma biochemical parameters in adult male rats.

\section{MATERIALS AND METHODS}

\section{Animals}

Male wistar rats (S I P H A T, Tunisia), weighing at the beginning of the experiment from 195 to $200 \mathrm{~g}$ were randomly divided into control group $(n=6)$ and SMF exposed rats $(n=6)$. Control and SMF exposed rats were kept in similar conditions under room air. The animals were maintained in normoxic conditions and were housed in groups of six in stainless-steel cages at $25^{\circ} \mathrm{C}$, under a $12-12$ light /dark cycle, with free access to basal diets and water. Animals were cared under the Tunisian code of practice for the Care and Use of Animals for Scientific Purposes. The experimental protocols were approved by the Faculty Ethics Committee.

\section{Exposure system}

Lake Shore Electromagnets (Lake Shore Cryotronic, Inc, Westerville Ohio, USA) were compact electromagnets used for magnetic resonance demonstrations. Water-cooled coils provided excellent field stability and uniformity when high power was required to achieve the maximum field capability for the electromagnet (Abdelmelek et al., 2002).

\section{Magnetic field intensity and exposure scenario}

The intensity of magnetic field was measured and standardized in the total floor area of the Plexiglas cage at $128 \mathrm{mT}$. The cage had $20 \mathrm{~cm}$ length, $10 \mathrm{~cm}$ width and $20 \mathrm{~cm}$ height. The two bobbins of the Lake shore System were separated by the distance of $12 \mathrm{~cm}$. Adult male rats were exposed to static magnetic field $(128 \mathrm{mT})$ in the Plexiglas cage between the two bobbins of the Lake Shore System, $1 \mathrm{~h}$ /day (between 9h-12h) during 5 days for sub-acute exposed group and during 30 days for sub-chronic exposed group. The cage in the Lake Shore contained two rats for each exposure. The control rats were positioned in the Lake Shore system one hour/day (between 9h-12h) during 30 days without applying magnetic field.

\section{Blood sampling protocol}

Blood samples (0.5m1 approximately/sample) were collected in vials containing EDTA for haematological investigations or heparin for biochemical studies. Haematological parameters were assayed by Medonic-precision instruments for haematology research (CA620).

\section{Blood chemistry}

Control and treated rats were scarified immediately after the last exposure. Blood collected in heparinized chilled tubes was immediately centrifuged. Aliquots of plasma were frozen and stored at $-80^{\circ} \mathrm{C}$ prior to biochemical analysis. Plasma LDH, aspartate aminotransferase (AST) and alanine aminotransferase (ALT) were measured using the enzymatic methods according to manufacturer instructions (ChronoLabo, France). The protein levels were measured using the Bradfort methods. Plasmatic glucose concentrations were measured using the glucose oxidize methods according to manufacturer instructions (SIGMA Diagnostics; glucose "TRINDER ").

\section{Data presentation and statistical analysis}

Data are reported as the mean \pm SEM. Statistical significance of the differences between means was assessed by Student's t-test. The level of significance was set at $\mathrm{p}<0.05$.

\section{RESULTS}

Exposure of rats to SMF at $128 \mathrm{mT}$ resulted in a non-significant reduction in growth rate following 
7 days of treatment. But a significant reduction in growth rate was noted after 14 or 21 days of treatment compared to controls (Fig. 1). Subchronic exposure to SMF did not affect water consumption in rats (Table 3). However, sub-acute exposure to SMF induced an increase of plasmatic LDH activity $(641.42 \pm 36.11 \mathrm{U} / \mathrm{L}$ vs $462.91 \pm$
$31.38 \mathrm{U} / \mathrm{L}, \mathrm{p}<0.05$ ) (Table 2), and glucose concentration $(1.63 \pm 0.1 \mathrm{~g} / 1$ vs $1.23 \pm 0.05 \mathrm{~g} / 1$, $\mathrm{p}<0.05$ ) (Fig. 3), while haematological parameters, plasmatic total protein levels, alanine aminotransferase and aspartate aminotransferase activities remained unchanged in SMF rats (Table 1-2, Fig. 2).

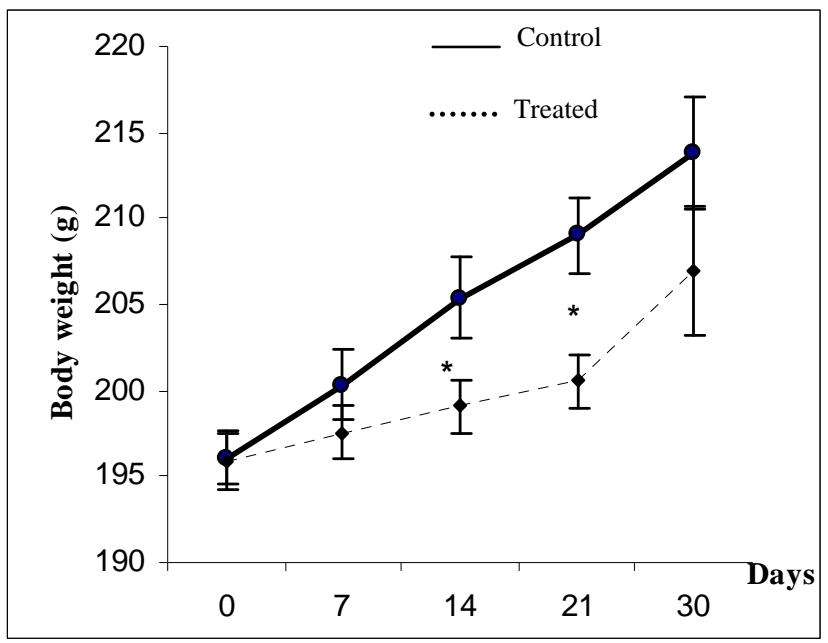

Figure 1 - Effect of exposure to static magnetic field on growth rate in rats. C (control); SMF (Static Magnetic Field). Values are means \pm SEM calculated from $n=6$ in each group. ${ }^{*} \mathrm{p}<0.05$, compared to control.

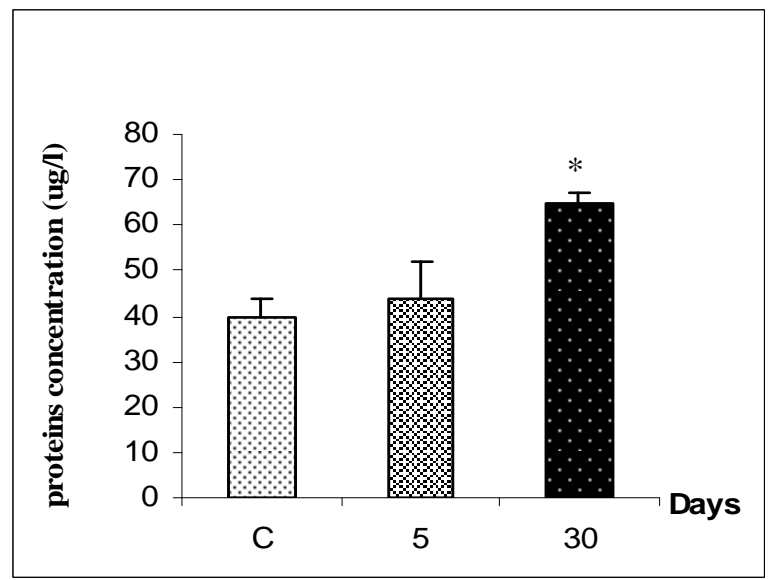

Figure 2 - Effect of sub-acute (5 days) and sub-chronic (30 days) exposure to static magnetic field on plasmatic protein concentration. Values are means \pm SEM calculated from $n=6$ in each group. ${ }^{*} \mathrm{p}<0.05$, compared to control

However, SMF exposure of rats during 30 consecutive days (1h/day at $128 \mathrm{mT})$ increased significantly plasmatic protein levels $(65 \pm 2 \mu \mathrm{g} / 1$ vs $40 \pm 4 \mu \mathrm{g} / 1, \mathrm{p}<0.05$ ) (Fig. 2), haemoglobin $(13.2 \pm 0.26 \mathrm{~g} / \mathrm{dl}$ vs $11.98 \pm 0.15 \mathrm{~g} / \mathrm{dl}, \mathrm{p}<0.05)$, the number of red blood cells $\left(7.82 \pm 0.1510^{6} / \mathrm{mm}^{3}\right.$ vs 
$\left.7.29 \pm 0.0310^{6} / \mathrm{mm}^{3}, \mathrm{p}<0.05\right)$, white blood cells $\left(13.68 \pm 1.4210^{3} / \mathrm{mm}^{3}\right.$ vs. $11.35 \pm 0.1610^{3} / \mathrm{mm}^{3}$, $\mathrm{p}<0.05)$, and platelet levels $\left(626 \pm 14.0410^{3} / \mathrm{mm}^{3}\right.$ vs $\left.566.33 \pm 15.0810^{3} / \mathrm{mm}^{3}, \mathrm{p}<0.05\right)$ (Table 1$)$.

Sub-chronic treatment with SMF elevated also the lactate dehydrogenase $(661.92 \pm 34.26 \mathrm{U} / \mathrm{L}$ vs $462.91 \pm 31.38 \quad \mathrm{U} / \mathrm{L}, \quad \mathrm{p}<0.05), \quad$ aspartate aminotransferase $(31.81 \pm 1.61 \mathrm{U} / \mathrm{L}$ vs $22.6 \pm$ $1.85 \mathrm{U} / \mathrm{L}, \mathrm{p}<0.05)$ and alanine aminotransferase activities $(43.56 \pm 3.56 \mathrm{U} / \mathrm{L}$ vs $22.31 \pm 2.27 \mathrm{U} / \mathrm{L}$, $\mathrm{p}<0.05$ ) (Table 2), whereas the plasmatic glucose concentration remained unchanged $(1.428 \pm 0.04$ g/1 vs $1.23 \pm 0.05$ g/1, p>0.05) (Fig. 3).

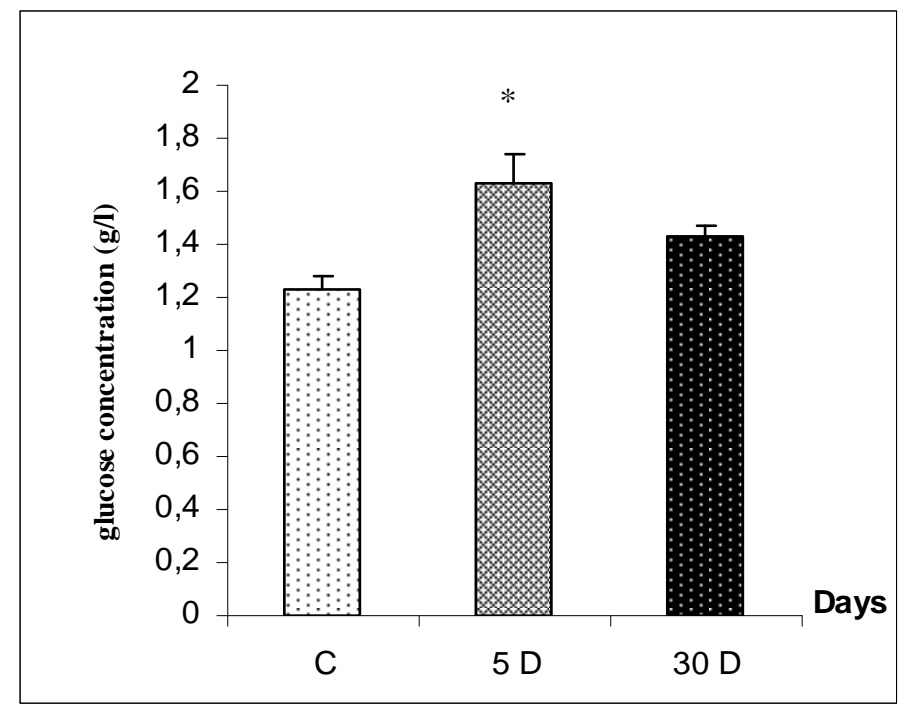

Figure 3 - Effect of sub-acute (5 days) and sub-chronic (30 days) exposure to static magnetic field on plasmatic glucose concentration. Values are means \pm SEM calculated from $n=6$ in each group. ${ }^{*} \mathrm{p}<0.05$, compared to control.

\section{DISCUSSION}

The results showed that exposure to SMF originated different metabolic and hematological disruption, which appeared to be related to the duration of exposure. Exposure to SMF (1h/day) induced a decrease of body weight by the second week of treatment. Moreover, the same treatment caused an increase of hemoglobin concentration, white blood cells, red blood ce11s and platelets count compared to control rats, whereas hematocrit levels remained unchanged. The increase of hemoglobin and red blood ce11s levels could be explained by the installation of an hypoxia-like status following sub-chronic exposure to SMF. However, the precise way in which SMF induced an hypoxia-like status has not yet been fu11y clarified. The hypothesis of an action of SMF on the geometrical conformation of hemoglobin was reinforced by the fact that SMF induced a prominent effect on the hemoglobin structure as previously demonstrated by Pries et al
(1992). The evidence that SMF acts to decrease body weight and unaffected water consumption raises the question of how SMF alter body weight. Nevertheless, the body weight decrease could not be related to dehydration but probably to the hypoxia status known to alter the body weight (Necka et al., 2003). Previous studies showed that chronic hypoxia was associated with increased oxidative stress as evidenced by marked lipid peroxidation and the induction of antioxidant enzyme response in various tissues and organs (Yoshikawa et al., 1982; Nakanishi et al., 1995). Interestingly, literature analysis showed a lack of data regarding the effects of static magnetic field in biological system. However, previous investigations identified the effects of radiofrequency and electromagnetic field in animals. Sevedenstal et al (1998) has shown a significant lower body weight of male mice exposed to electromagnetic field. Moreover, Stanis et al (2001) pointed to the existence of an increase of haematological parameters on lactating ewes 
exposed to a pulsed electromagnetic field. On the contrary, Dacha et al (1993) did not observe any significant modification in human erythrocytes exposed in vitro to electromagnetic field. This study showed that sub-acute exposure to SMF increased significantly plasmatic LDH activity, but had no effect on those of ALT and AST. However, sub-chronic exposure of rats to SMF lead to increase $\mathrm{LDH}$ and transaminases activities. Thus, the increase of LDH and plasmatic transaminases levels could be attributed to the alteration of hepatocytes. Previous studies showed that these enzymes were increased in nearly all pathological states in which damage or cellular destruction was produced (Martin et al., 2000). These results were in accordance with the findings of Boguslow et al (1999) showing an elevation of AST and ALT in steelworkers exposed to magnetic field. Magnetic field also induced structural changes in hepatocytes, primarily in mitochondria (Parafiniuk et al., 1992). Bonhomme et al. (1998) showed a non significant difference in LDH activity of mice after exposure to magnetic field. Present results showed that sub-acute but not sub-chronic exposure to SMF significantly increased g1ycemia. The hyperg1ycemia observed following sub-acute exposure to SMF could be explained by structural and functional changes in pancreas, in response to SMF stress. The lack of effect on glycemia observed in sub-chronic exposed rats suggested probably an adaptative response of carbohydrate metabolism subsequent to a long exposure. Comparative data were reported by Gorczynska et al (1991) who observed a slight increase of serum glucose concentration, associated with a decrease of insulin and an increase of glucagon levels in rats exposed to magnetic field. Present data showed that SMF exposure increased plasmatic total protein levels suggesting the change in protein metabolism of stressed rats. In steelworkers exposed to electromagnetic field, Boguslow et al. (1999) showed a slight decrease of total serum protein levels. This discrepancy could be attributed to the difference of the intensity of the SMF and the exposure scenario and duration. The mechanism of SMF action in biological systems can be examined by its interaction with moving charges and enzymes activities rates in cell-free systems increasing transcript levels for specific genes (Goodman et al., 2002). It is likely. However, SMF also interact directly with electrons in DNA to affect protein biosynthesis (Goodman et al., 2002).

In conclusion SMF exposure originated different metabolic and hematological effects, which appeared to be related to the duration of exposure. The change in biochemical parameters of SMFexposed rats reflected probably hepatic damage. Further studies are needed for the better understanding of the SMF effects in biological system.

Table 1 - Effect of sub-acute (5 days) and sub-chronic (30 days) exposure to static magnetic field on blood cells count..

\begin{tabular}{cccccc}
\cline { 2 - 5 } & $\mathbf{W B C}\left(\mathbf{1 0}^{\mathbf{3}} / \mathbf{m m}^{\mathbf{3}}\right)$ & $\mathbf{R B C}\left(\mathbf{1 0}^{\mathbf{6}} / \mathbf{m m}^{\mathbf{3}}\right)$ & $\mathbf{H b}(\mathbf{g} / \mathbf{d l})$ & $\mathbf{H t}(\boldsymbol{\%})$ & $\mathbf{P L T}\left(\mathbf{1 0}^{\mathbf{3}} / \mathbf{m m}^{\mathbf{3}}\right)$ \\
\hline C & $11.35 \pm 0.16$ & $7.29 \pm 0.03$ & $11.98 \pm 0.15$ & $34.06 \pm 0.32$ & $566.33 \pm 15.08$ \\
SMF (5 days) & $11.88 \pm 0.39$ & $7.33 \pm 0.19$ & $12.73 \pm 0.11$ & $35.32 \pm 0.77$ & $607.6 \pm 31.83$ \\
SMF (30days) & $13.68 \pm 1.42^{*}$ & $7.82 \pm 0.15^{*}$ & $13.2 \pm 0.26^{*}$ & $35.37 \pm 0.69$ & $626 \pm 14.04 *$
\end{tabular}

WBC (White blood cell); RBC (Red blood cell); Hb (Hemoglobin); Ht (Hematocrit); PLT (platelet); C (control); SMF (static magnetic field). Values are means \pm SEM calculated from $n=6$ in each group. $* \mathrm{P}<0.05$, compared to control.

Table 2 - Effect of sub-acute (5 days) and sub-chronic (30 days) exposure to static magnetic field on serum LDH and transaminases activities.

\begin{tabular}{cccc} 
& LDH $(\mathbf{U} / \mathbf{L})$ & AST $(\mathbf{U} / \mathbf{L})$ & ALT $(\mathbf{U} / \mathbf{L})$ \\
\hline $\mathbf{C}$ & $462.91 \pm 31.38$ & $22.6 \pm 1.85$ & $22.31 \pm 2.27$ \\
SMF 5 days & $641.42 \pm 36.11^{*}$ & $23.5 \pm 1.2$ & $24 \pm 1.68$ \\
SMF 30 days & $661.92 \pm 34.26^{*}$ & $1.81 \pm 1.61^{*}$ & $43.56 \pm 3.56^{*}$ \\
\hline
\end{tabular}

LDH (Lactate dehydrogenase); AST (aspartate aminotransferase); ALT (alanine aminotransferase); C (control); SMF (Static Magnetic Field). Values are means \pm SEM calculated from $n=6$ in each group. ${ }^{*} p<0.05$, compared to control. 
Table 3 - Effect of sub-chronic exposure to static magnetic field in water consumption in rats.

\begin{tabular}{ccccc} 
& W1 & W2 & W3 & W4 \\
\hline $\begin{array}{c}\mathbf{C} \\
\mathrm{ml} / 24 \mathrm{~h} / \text { Rat } \\
\mathbf{S M F}\end{array}$ & $20.76 \pm 0.44$ & $19.42 \pm 0.61$ & $20.04 \pm 0.49$ & $19.78 \pm 0.7$ \\
$\mathrm{ml} / 24 \mathrm{~h} /$ Rat & $21.04 \pm 0.45$ & $21.69 \pm 0.6$ & $20.45 \pm 0.64$ & $21.3 \pm 0.31$ \\
\hline
\end{tabular}

C (control); SMF (Static Magnetic Field); W (week). Values are means \pm SEM calculated from $n=6$ in each group.

\section{ACKNOWLEDGMENTS}

This study was supported by the Secretary of Scientific Research and Technology Tunisia and 1.abo Environnemental Biomonitoring. We thank Bechir Azib for his excellent technical assistance.

\section{RESUMO}

Este estudo foi realizado com o obejtivo de investigar os efeitos do campo magnético estático (CMS) nas taxas de crescimento, hematopoiese, concentrações de proteínas plasmáticas, glicemia, da desidrogenase lática (DHL) e transaminases (alanina aminotransferase-ALT e aspartato aminotransferase-AST) em ratos machos. Após exposição de modo sub-agudo durante 5 dias consecutivos ao CMS (1 hora/dia, a 128mT), houve aumento em $38 \%$ na concentração de DHL $(\mathrm{p}<0.05)$, porém não houve mudanças nos índices hematimétricos, nas proteínas plasmáticas e nas transaminases. Duas semans após exposição ao CMS durante 30 dias consecutivos (CMS (1 hora/dia, a $128 \mathrm{mT}$ ) houve diminuição significativa das taxas de crescimento e aumento significativo das concetrações de proteínas $(+62 \%, \mathrm{p}<0.05)$, da hemoglobina $(+10 \%, \mathrm{p}<0.05)$, eritrócitos $(+7 \%$, $\mathrm{p}<0.05)$, leucócitos $(+17 \%, \mathrm{p}<0.05)$ e plaquetas $(+10 \%, p<0.05)$. A exposição sub-crônica ao CMS induziu aumento da DHL $(+43 \%, \mathrm{p}<0.05)$, AST $(+$ $41 \%, \mathrm{p}<0.05)$ e ALT $(+95 \%, \mathrm{p}<0.05) . \quad \mathrm{Em}$ contraste não houve aumento da glicemia.

Estas alterações sugerem que a exposição ao CMS possivelmente influencia a proliferação de células do sistema hematopoiético e a produção enzimática, indicando alterações teciduais.

\section{REFERENCES}

Abdelmelek, H.; Amara, S.; M'Chirgui, A.; Ben Salem, M., and Sakly, M. (2002), Effect of acute exposure to magnetic field on electrical properties of sciatic nerves: Biosuperconductivity. Biomag, 1109-1121.

Abdelmelek, H.; Chater, S. and Sakly, M. (2001), Acute exposure to magnetic field depresses shivering thermogenesis in rat. Biomedizinische TechnikBand46-Ergiinzungsband., 2, 164-166.

Abdelmelek, H.; Chater, S.; Smirani, R.; M'Chirgui, A.; Ben Jeddou, C.; Ben Salem, M. and Sakly, M. (2000), Effects of $50 \mathrm{~Hz}$ sinusoidal waveform magnetic field on dehydrated rat body. Millennium International Workshop on Biological Effects of Electromagetic fields, 474-479.

Baum, A.; Mevissen, M. and Kamino, K. (1995), A histological study on alteration in DMBA-induced mammary carcinogenesis in rats with $50 \mathrm{~Hz}, 100$ muT magnetic field exposure carcinogenesis. v. 16. pp. 119-125.

Boguslaw, K.; Andrzej, S.; Rozalia, G. and Danuta, P. (1999), Effect of Electromagnetic Field on Serum Biochemical Parameters in Steelworkers. J. Occup Health., 41, 177-180.

Bonhomme-Faive, L.; Mace, A.; Bezie, Y.; Marion, S.; Bindoula, G.; Szekely, A. M.; Frenois, N.; Auclair, H.; Orbach-Arbouys, S. and Bizi, E. (1998), Alterations of biological parameters in mice chronically exposed to low-frequency $(50 \mathrm{~Hz})$ electromagnetic fields. Life Sci., 62, 1271-1280.

Chemysheva, O. N. (1990), Status of the lipid phase of plasma membranes of the heart after repeated exposure to altemate magnetic of $50 \mathrm{~Hz}$ frequency. Kosm Biol. Aviakosm Med., 24, 30-31.

Dacha, M. O.; Accorci, A. and Pierotti, C. (1993), Studies on the possible biological effects of $50 \mathrm{~Hz}$ electric and/or magnetic fields: evaluation of some glycolytic enzymes, glycolytic flux, energy and oxido-reductive potentials in human erythrocytes exposed in vitro to power frequency fields. Bioelectromagnetics., 14, 383-391.

Day, N. (1999), Exposure to power-frequency magnetic fields and the risk of childhood cancer. Lancet., 354, 1925-1931. 
Goodman, R. and Blank, M. (2002), Insights into electromagnetic interaction mechanisms. J. Cell Physiol., 192 :(1), 16-22.

Gorczynska, E. and Wegrzynowics, R. (1991), Glucose homeostasis in rats exposed to magnetic fields. Invest Radiol., 26, 1095-1100.

Hatch, E. E.; Linet, M. S.; Kleinerman, R. A; Tarone, R. E., Severson, R. K; Hartsock, C. T.; Haines, C.; Kaune, W. T., Friedman, D., Robison, L. L and Wacholder, S. (1998), Association between childhood acute lymphoblastic leukemia and use of electrical appliances during pregnancy and childhood. Epidemiology, 9, 234-245.

High, W. B.; Sikora, J.; Ugurbil, K. and Garwood, M. (2000), Subchronic in vivo effects of a high static magnetic field $(9.4 \mathrm{~T})$ in rats. Journal of Magnetic Resonancelmaging., 12, 122-139.

Jolanta, J.; Janina, G.; Marek, Z.; Elzibieta, R.; Mariola, S. and Marek, K. (2001), Influence of $7 \mathrm{mT}$ static magnetic field and irons ions on apoptosis and necrosis in rat blood lymphocytes. J. Accup. Health, 43, 379-381.

Kula, B.; Grzesik, J.; Wardas, M.; Kuska, R. and Goss, M. (1991), Effect ofmagnetic field on the activity of hyaluronidase and D-glukuronidase and the level hyaluronic acid and chondroitin sulfates in rat liver. Ann Acad Med Sil., 24, 77-81.

Lacy-Hulbert, A.; Metcalfe, J. C. and Hesketh, R. (1998), Biological responses to electromagnetic fields. FASEB J., 12, 395-420.

Marino, C.; Antonini, F. O.; Avella, B, O.; Galloni, L. and Scacchi, P. (1995), $50 \mathrm{~Hz}$ magnetic field effects on tumoral growth in vivo systems. In: Annual BEMS Meeting, 7., Boston. Proceedings ... Massachusetts: Book. pp. 171-172.

Martin, J. A.; Blanco, M. D.; Olmo, R.; Gomez, C. and Teijon, J. M. (2000), Acute adminatration of beryllium in rats: renal, hepatic and hematological effects and implication of the plasmatic lysosymes levels. Ecotoxicological and Environmental Restoration, 3 :(1).

Mevissen, M.; Kietzmann, M. and Loscher, W. (1995), In vivo exposure of rats to a weak altemating magnetic field increases omithine decarboxylase activity in the mammary gland by a similar extent as the carcinogen DMBA. Cancer Lett., 90, 207-214.

Nagashima, K.; Nikkei, S.; Tanaka, M. and Kanosue, K. (2000), Neuronal circuitries involved in thermoregulation. Auton Neurosci., 85, 18-25.

Nakanishi, K.; Tajima, F.; Nakamura, A.; Yagura, S.; Ookawara T.; Yamashita, H.; Suzuki, K.; Taniguchi, N. and Ohno, H., (1995), Effect of hypobaric hypoxia on antioxidant enzymes in rats. J. Physiol. Lond., 489, 869-876.
Necka, J.; Szarszoi, O.; Herget, J.; Adal, B. O. and Kola, F. (2003), Cardioprotective Effect of Chronic Hypoxia is Blunted by Concomitant Hypercapnia Physiological Research.

Parafiniuk, M.; Gorczynska, E.; Gutsch, A. and Parafiniuk, W. (1992), Effect of constant magnetic field on the liver of guinea pig. Electron microscopic studies. Folia Histochem Cytobiol., 30 :(3), 119-23.

Pries, A. R.; Neuhaus, D. and Gaehtegnes, P. (1992), Amer. Physiol. Scoi., 263, H1170.

Reipert, B. M.; Allan, D.; Reipert, S. and Dexter, T. M., (1997), Apoptosis in haemopoietic progenitor cells exposed to extremely low-frequency magnetic fields. Life Sci., 61, 1571-1582.

Stanis, A. W.; Wiesaw, S.; Andrzej, D. and Andrzej, R., (2001), ElectronicEffect of pulsed electromagnetic fields on hematological and biochemical blood indices and milk production in sheep. Jounal of Polish Agricultural Universities Series Veterinary medicine, $4:(2)$.

Thomson, R. A.; Michaelson, S. M. and Nguyen, Q. A. (1988), Influence of 60-Hertz magnetic fields on leukemia. Bioelectromagnetics., 9, 149-158.

Yoshikawa, T.; Furukawa, Y.; Wakamatsu Y.; Takemura, S.; Tanaka, H. and Kondo, M., (1982), Experimental hypoxia and lipid peroxide in rats. Biochem Med., 27.
Received: June 21, 2005; Revised: April 07, 2005; Accepted: August 17, 2006. 